\title{
Kryzys Kościoła jako kryzys wartości w niemieckim dyskursie teologiczno-socjologicznym
}

$\bigvee_{\text {i obserwatorów życia spoęecznego bardzo często pojawia się motyw kry- }}^{\text {ciagu }}$ zysu. Ma on różne wymiary: mowa jest o kryzysie gospodarczym, politycznym, klimatycznym, o kryzysach związanych z epidemiami chorób, o kryzysie rodziny czy autorytetów. Termin „kryzys” odnoszony jest również do współczesnej sytuacji religii i Kościoła. Zjawiska takie jak znaczący spadek uczestnictwa w praktykach religijnych, wpływów instytucjonalnej religii na życie jednostek i społeczeństw, a także liczby osób wybierających powołanie religijne, już od dłuższego czasu wyraźnie widoczne w krajach Europy Zachodniej, dotykają obecnie również krajów i regionów, które tradycyjnie stanowiły ostoję katolicyzmu. Niektórzy badacze są zdania, że zjawiska te stanowią dowód na słuszność tezy sekularyzacji w jej radykalnej wersji, zakładającej niekompatybilność światopoglądów religijnych z trendami modernizacyjnymi. Inni z kolei - w tym również niektórzy hierarchowie - skłaniają się raczej ku tezie dechrystianizacji, wskazując, że wartości istotne dla współczesnej kultury mogą stanowić bezpośrednie zagrożenie dla wartości chrześcijańskich.

Nie ulega wątpliwości, że sytuacji Kościoła u progu trzeciej dekady XXI stulecia nie da się porównać z tym, jak przedstawiała się ona jeszcze w połowie minionego wieku. Warto jednak zwrócić uwagę na to, że w większości przypadków nie jest ona spowodowana tym, iż współczesny człowiek odrzuca religię

* Dr hab. Agnieszka Zduniak, prof. UKSW, Uniwersytet Kardynała Stefana Wyszyńskiego w Warszawie, Instytut Nauk Socjologicznych, e-mail: a.zduniak@uksw.edu.pl, ORCID: 00000001-5349-7469. 
w ogóle lub odnosi się z wrogością do chrześcijaństwa. Różne formy religii czy duchowości, a także wartości wywodzące się z religii chrześcijańskiej są nadal cenione; można wręcz powiedzieć, że mają się zaskakująco dobrze w zsekularyzowanych ponoć społeczeństwach Zachodu. Problem dotyczy więc innej kwestii. Zjawiska określane zbiorczym terminem „kryzys” na ogół nie odnoszą się do samej religii - ani w jej ogólnym rozumieniu, ani w znaczeniu religii chrześcijańskiej. Odnoszą się natomiast do Kościoła jako instytucji. Mamy tu do czynienia z sytuacją paradoksalną - większościowa akceptacja religii powinna teoretycznie iść $\mathrm{w}$ parze z przywiązaniem do jej społecznego reprezentanta. Wzrastający dystans wobec instytucji Kościoła skłania do poszukiwania jego przyczyn.

W niniejszym opracowaniu zostaną przedstawione niektóre zjawiska kulturowe związane ze sferą wartości, które mogą przyczyniać się do obecnej sytuacji Kościoła. Za podstawę analizy posłuży toczący się od kilku dziesięcioleci w Niemczech dyskurs teologiczno-socjologiczny dotyczący możliwych przyczyn obecnych trudności Kościoła mających swoje źródło w sferze aksjonormatywnej, a także możliwych zmian strukturalnych oraz pastoralnych, które mogłyby się przyczynić do wzrostu wiarygodności i skuteczności głoszenia Ewangelii współczesnemu człowiekowi. Dyskusja ta może być interesująca również dla polskich badaczy zainteresowanych problematyką funkcjonowania Kościoła we współczesnym świecie. Choć bowiem jego sytuacja w społeczeństwie polskim nie jest identyczna z tą w Niemczech, to już dziś i w naszym kraju da się zauważyć pewne kulturowe tendencje, które mogą doprowadzić do tego, że Kościół w Polsce za kilkadziesiąt lat będzie musiał stawić czoła podobnym problemom, z jakimi dziś zmaga się Kościół katolicki za zachodnią granicą. Założenie, że tak się nie stanie, oparte na przekonaniu o „wyjątkowości” polskiego katolicyzmu na tle innych krajów europejskich, może okazać się ryzykowne, jeśli wziąć pod uwagę, że za podobnie wyjątkowy i odporny na zmiany uchodził przez lata katolicyzm w Irlandii lub też kanadyjskiej prowincji Quebec, której mieszkańców nazywano niegdyś „katolickimi z natury”.

\section{Czym właściwie jest kryzys?}

Termin „kryzys” jest używany na określenie szczególnego typu sytuacji w różnych dziedzinach życia społecznego. Słownik Języka Polskiego PWN podaje pięć różnych znaczeń tego terminu, z czego dla naszych rozważań przydatne wydają się dwa: „zachwianie jakiegoś systemu wartości lub pozycji czegoś” oraz „najcięższy, przełomowy moment w przebiegu choroby”. Mamy więc do czy-

1 https://sjp.pwn.pl/sjp/kryzys;2565070.html [dostęp: 27.11.2019]. 
nienia z sytuacją, w której jakiś stan uchodzący za normalność (obowiązywanie systemu wartości, stabilna pozycja czegoś lub kogoś, zdrowie) zostaje zakłócony. Zakłócenie takie musi mieć charakter na tyle długotrwały i dolegliwy, żeby - po pierwsze - zostało zauważone i zidentyfikowane jako kryzys; po drugie - żeby narzucało pytania o możliwe przyczyny i przewidywalne skutki. Stwierdzenie, że mamy do czynienia z kryzysem, łączy się z jednej strony z nadzieją jego rychłego zażegnania i powrotu do normalności, z drugiej zaś z lękiem przed ryzykiem, jakie z sobą niesie; przezwyciężenie kryzysu nie musi wszak oznaczać powrotu do status quo, lecz często wymusza pogodzenie się z nową sytuacją zdrowotną, polityczną, kulturową czy jeszcze inną. Stwierdzenie kryzysu w jakiejś dziedzinie życia społecznego - w makro- lub mikroskali - nieuchronnie wiąże się z niepokojem; termin ten ma wyraźny wydźwięk pejoratywny.

Zdaniem Krzysztofa Wieleckiego „o kryzysie cywilizacyjnym można mówić, gdy wyzwania cywilizacyjne uniemożliwiają istnienie społeczeństwa bez istotnych zmian. Czynnikami takiego kryzysu mogą być wielkie wydarzenia historyczne (jak wojny, rewolucje itp.), przyrodnicze (jak powodzie, trzęsienia ziemi itp.), albo też wielkie odkrycia naukowe i techniczne czy nowe religie, idee lub też wielkie racjonalizacje, wyobrażenia, mity" ${ }^{2}$. Marian Golka zauważa z kolei, że „kryzysowi zwykle towarzyszy dyskomfort oraz poczucie lęku i niepewności. Jest to pewien stan, w którym system stara się rozwiązać problem zmierzając jednocześnie ku przyszłości, bądź trwa z wiarą, że problemy rozwiążą się same. Może zdarzyć się, iż nie dotrze on do świadomości całej zbiorowości, co może stanowić utrudnienie w pokonywaniu jego przyczyn"3. W takiej perspektywie kryzys jest przeciwieństwem normalności, czymś, co ją zaburza i jej zagraża. Jest sytuacją niewygodną, ponieważ wymaga mobilizacji sił fizycznych i psychicznych, opracowania strategii działań przyszłych i krytycznej oceny przeszłych, podejmowania wysiłku.

W obliczu kryzysu sytuacja, która go poprzedzała, zanim jeszcze nastąpił, często jest idealizowana w procesie retrospekcji, jawiąc się jako normalność, czyli „to, co być powinno”. Warto jednak zastanowić się nad tym, co w dzisiejszych czasach należy rozumieć pod pojęciem „normalności”. Gerhard Schulze w interesującej analizie poświęconej współczesnym rozumieniom pojęcia kryzysu wyróżnia jej dwa typy. Pierwszy z nich jest tym, co najbardziej odpowiada potocznym intuicjom: normalność jako pewien stan, który albo wcale nie ulega zmianom, albo zmiany te następują w nim powoli, w sposób ewolucyjny i praktycznie nieodczuwalny. Drugi typ normalności, charakterystyczny dla społeczeństwa ponowoczesnego, to normalność rozumiana jako proces: stan

2 K. Wielecki, Kryzys i socjologia, Warszawa 2012, s. 331, por. J. Łodzińska, Zjawisko wypalenia zawodowego jako efekt zmian cywilizacyjnych. Studium socjologiczne na przykładzie pielegniarek podlaskich, Warszawa 2018, s. 18-19.

3 M. Golka, Cywilizacja. Europa. Globalizacja, Poznań 1999, s. 40-42. 
ciągłych zmian w różnych obszarach życia, zmian na tyle odczuwalnych, niejednokrotnie nawet gwałtownych, że można mówić w tym kontekście o stanie permanentnego kryzysu; z takiego punktu widzenia kryzys staje się niemal synonimem normalności ${ }^{4}$.

Scharakteryzowane w ten sposób typy normalności mają w oczywisty sposób idealnotypiczny charakter; nie sposób bowiem ani wyobrazić sobie społeczeństwa, które nie ulegałoby żadnym zmianom, ani też społeczeństwa, w którym brakowałoby struktur stabilnych, a każdy stan rzeczy mógłby w dowolnym momencie ulegać przekształceniom. Takie rozróżnienie wydaje się jednak owocne w przypadku rozważań dotyczących obszarów społecznego życia poddanych akcelerującym zmianom społecznym, kulturowym lub aksjologicznym. Poszczególne instytucje społecznego życia będą plasować się w różnych miejscach skali między „normalnością-stanem” a „normalnością-procesem”. Dotyczy to również Kościoła i jego problemów związanych z rzeczywistym lub domniemanym kryzysem.

\section{Kryzys Kościoła z punktu widzenia instytucji}

Na konglomerat zjawisk składających się na „kryzys” Kościołów chrześcijańskich w Europie złożyło się wiele przyczyn: rozpad stabilnych środowisk wyznaniowych, urbanizacja i wzrastająca mobilność społeczna, przemiany obyczajowe zapoczątkowane w latach 60., a także przyczyny ekonomiczne, jak np. fala masowych wystąpień z Kościołów w Niemczech spowodowana chęcią uniknięcia płacenia podatku kościelnego. W Kościele niemieckim wzrasta sukcesywnie liczba osób, które określają się jako bezwyznaniowe, a osoby wierzące coraz rzadziej angażują się w praktyki religijne i działania w obrębie wspólnot przykościelnych. Od dłuższego czasu widoczny jest także kryzys powołań: oblicza się, że obecnie każdy nowo wyświęcony kapłan musi zastąpić siedmiu wycofujących się z posługi. Przeciętny wiek duchownego katolickiego w Niemczech wynosi około 60 lat ${ }^{5}$. Ma to daleko idące skutki dla pracy duszpasterskiej: konieczność łączenia parafii uniemożliwia często bezpośrednie kontakty nadmiernie obciążonych pracą duchownych $\mathrm{z}$ wiernymi, a wzrastająca przeciętna wieku nie sprzyja wyjściu z impasu spowodowanego przez brak powołań (starsi księża nie stanowią już wzoru osobowego dla ludzi młodych).

Sytuację pogarsza ujawnienie (od $2010 \mathrm{roku}$ ) skandali obyczajowych i finansowych związanych z niektórymi przedstawicielami duchowieństwa. Od dłuższego czasu spada poziom akceptacji wartości i norm głoszonych przez Kościół

${ }^{4}$ G. Schulze, Krisen, Zürich 2010, s. 25.

5 M.N. Ebertz, Erosion der (katholischen) Kirche. Altes flicken oder neues wagen?, w: P. Becker, U. Diewald, Die Zukunft von Religion und Kirche in Deutschland, Freiburg im Breisgau 2014, s. 38. 
(szczególnie w dziedzinie moralności małżeńskiej i seksualnej). Wszystkie te czynniki wywierają niekorzystny wpływ na wizerunek Kościoła i prowadzą do coraz częstszego formułowania postulatów zmian strukturalnych i reformy duszpasterstwa. Nic więc dziwnego, że socjologowie i teologowie z krajów Europy Zachodniej dość wcześnie zaczęli definiować zmieniającą się sytuację instytucji religijnych w kategoriach kryzysu. Niektóre z diagnozowanych przyczyn związane są z ogólnospołecznymi zmianami kulturowymi, inne z kolei wynikają z czynników wewnątrzkościelnych, i to zarówno tych, które odnoszą się do codziennego funkcjonowania Kościoła jako instytucji, jak i do szczególnych wydarzeń w jego obrębie.

Wśród wskazywanych przez niemieckojęzycznych badaczy przyczyn kryzysu Kościoła mających swoje źródło w sferze aksjonormatywnej można zasadniczo wyróżnić trzy kategorie. Pierwsza $\mathrm{z}$ nich związana jest $\mathrm{z}$ dysonansem między niektórymi wymaganiami Kościoła a dominującą w społeczeństwach zachodnich hierarchią wartości. Druga kategoria przyczyn ma swoje źródło w instytucjonalnej specjalizacji Kościołów. Zasada reprezentowania Kościoła wyłącznie przez osoby duchowne oraz ustanowienie prawa kanonicznego odrębnego od prawa państwowego sprawia, że Kościół postrzegany jest coraz częściej jako grupa obca („oni”), a nie grupa własna („my”), co z kolei ma daleko idące skutki dla internalizacji norm i wartości religijnych. Trzecia kategoria to przyczyny związane ze zjawiskiem, które można określić jako transfer wartości. Jego istotą jest to, że wartości stanowiące kwintesencję chrześcijaństwa zostają w dużej mierze włączone w kulturę świecką, przez co przestają być kojarzone zarówno z Kościołem, jak i w ogóle z chrześcijaństwem. Kościół natomiast coraz bardziej utożsamiany jest $\mathrm{z}$ mniej istotnymi aspektami chrześcijaństwa (głównie z wymiarem organizacyjno-rytualnym), które dla współczesnego człowieka są mało istotne ${ }^{6}$.

Szwajcarsko-niemiecki socjolog Franz-Xaver Kaufmann już w latach 60. wypowiadał się na temat różnych interpretacji kryzysu w Kościele następująco:

„Niektórzy kryzysowi temu przypisują szeroki zasięg, interpretując go jako kryzys religii czy chrześcijaństwa w ogóle, inni sądzą, że jest to kryzys wewnątrz Kościoła, wynikający z niedostatecznych zdolności przystosowawczych tzw. «Kościoła urzędowego». Trzecia grupa, do której wydaje się należeć znaczna część hierarchii, jest zdania, że w ogóle nie ma kryzysu, który odnosiłby się do Kościoła, jest najwyżej kryzys społeczny, którego pożałowania godnymi ofiarami są ci wszyscy, którzy nie mogą zaakceptować tradycyjnych form społecznych katolicyzmu"”.

6 F.-X. Kaufmann, Wie überlebt das Christentum?, Freiburg 2000, s. 99.

7 F.-X. Kaufmann, Kirche begreifen. Analysen und Thesen zur gesellschaftlichen Verfassung des Christentums, Freiburg 1979, s. 95. 


\section{Przemiany ogólnospołecznej hierarchii wartości a sytuacja Kościoła}

Podstawowym elementem kultury każdego społeczeństwa jest uznawana w nim hierarchia wartości. To, co stanowiło cel dążeń, a nierzadko sens życia ludzi żyjących w przeszłości (odległej lub całkiem niedawnej), niekoniecznie musi wydawać się równie cenne i ważne ludziom współczesnym. Słynne badania zapoczątkowane przez Ronalda Ingleharta w latach 70. XX wieku w wyrazisty sposób ukazują proces przemian hierarchii wartości. Wartości priorytetowe społeczeństwa nowoczesnego (o względnie niskim poziomie bezpieczeństwa egzystencjalnego) związane były z mieszczańskim etosem pracy. Ceniono więc prawo i porządek, sumienne wykonywanie wszelkich powinności, dopasowanie się do społecznych wymagań, dążenie do dobrobytu poprzez pracowitość i oszczędność, dyscyplinę i wypełnianie obowiązków. Za zalety uchodziły: posłuszeństwo, podporządkowanie, uczciwość, pilność, skromność, samoopanowanie, powściągliwość. Te powszechnie (lub co najmniej większościowo) cenione wartości społeczeństw zachodnich zostały zastąpione przez wartości postmaterialistyczne. Różnią się one znacząco od tych, które stały na szczycie hierarchii wartości społeczeństw nowoczesnych, ponieważ ukonstytuowały się w odmiennych warunkach: bezpieczeństwa bytowego oraz ekonomicznego. Ich wspólną cechą jest silne ukierunkowanie na jednostkę, a nie na szerzej pojętą społeczność. Wysoko cenione są więc: podmiotowość, możliwość samorealizacji, autentyczność, równość i demokracja. Wszystkim przyznaje się prawo do wolności i autonomii (w tym również do podważania autorytetów), a także zaspokajania potrzeb intelektualnych i estetycznych ${ }^{8}$. Obowiązuje zasada tolerancji, akceptacji dla odmienności, otwartości na inne kultury, religie, grupy etniczne i style życia.

W krajach zachodniego kręgu kulturowego nastąpiło znaczne podwyższenie poziomu dobrobytu i szybki rozwój nowych technologii. Umowy międzynarodowe umożliwiają coraz bardziej bezproblemowe przekraczanie granic, podróżowanie, poznawanie innych społeczeństw, kultur i sposobów życia. Błyskawiczny rozwój mediów daje dostęp do wszelkich informacji, rozszerza horyzonty i sprawia, że człowiek współczesny zyskuje świadomość ogromu możliwości, z których może skorzystać. Upowszechnienie edukacji, skrócenie czasu pracy oraz równouprawnienie kobiet powodują, że jednostka może sama zdecydować, jaki styl życia jest dla niej właściwy, niekoniecznie dostosowując się do tradycji środowiska, z którego pochodzi. Przyspieszone tempo rozwoju społecznego niesie ze sobą szybkie zmiany warunków życia, szczególnie młodszych pokoleń. Modernizacja i związana z nią pluralizacja sposobów życia poddaje w wątpliwość wszystkie hierarchie wartości, w szczególności te oparte

8 R. Inglehart, The silent Revolution, Princeton 1977. 
na tradycji. Nie jest już ona pielęgnowana jako rodzaj zasobu, który winien być przekazywany kolejnym pokoleniom w niezmienionej formie, lecz traktowana utylitarystycznie, niekiedy jako relikt życia społecznego mający w najlepszym wypadku wartość historyczno-sentymentalną. W takich warunkach słabnie wpływ rodziny i tradycyjnych autorytetów, natomiast większe znaczenie w procesie socjalizacji zyskują środowiska rówieśnicze, instytucje edukacyjne i media9.

Nietrudno zauważyć, że takie zmiany będą wywierać silny wpływ na stosunek do instytucji Kościoła, przede wszystkim w kwestii stosowania się do jego wymogów normatywnych. Zmiana jego sytuacji we współczesnym społeczeństwie wynika w dużej mierze z przekształceń struktury społecznej. W społeczeństwach tradycyjnych z hierarchiczną strukturą liczył się autorytet urzędu: ważniejsze niż treść przekazu było to, kto był jego autorem. Również w jednolitych środowiskach wyznaniowych nauczanie Kościoła stanowiło rodzaj metanarracji kształtującej ludzkie wyobrażenie o rzeczywistości i wyznaczającej każdemu miejsce w porządku świata. Obecnie w sytuacjach, w których jednostka doświadcza konfliktu między własnymi dążeniami a jego nauczaniem, o wiele częściej niż niegdyś jest skłonna do podejmowania decyzji zgodnych raczej z własnymi przekonaniami. Najczęściej odrzucane są te spośród norm ustalonych przez Kościół, które nie odnoszą się bezpośrednio do sfery wiary i praktyk religijnych, lecz dotyczą życia prywatnego lub stosunków społecznych. Tendencja do kontestowania odgórnie ustalonych wymogów normatywnych jest zresztą widoczna nie tylko w odniesieniu do Kościoła, lecz również innych instytucji i autorytetów społecznych.

W tej sytuacji łatwo przewidzieć i wskazać osie konfliktu między społecznie cenionymi wartościami a wartościami głoszonymi przez instytucjonalny Kościół. Zasada równości i demokracji nie przystaje do zasady hierarchiczności, zasada samostanowienia do wymogu posłuszeństwa, prawo do wyrażania i bronienia własnych poglądów w dialogu i dyskusji - do nauczania ex cathedra. Akceptacja pluralizmu poglądów i przekonań jest trudna do pogodzenia z kościelnym roszczeniem do reprezentowania jedynej prawdy. Wśród wartości społecznie cenionych naczelne miejsce zajmują te ukierunkowane na życie "tu i teraz", a nie na przyszłość (życie wieczne).

Wiele kwestii, które w Kościele pozostają niezmienne z przyczyn dogmatycznych, pozostaje w sprzeczności z tym, co we współczesnym społeczeństwie jest szeroko akceptowane. Do takich kwestii należy problem roli kobiet w Kościele, niektóre wymogi dotyczące moralności seksualnej i małżeńskiej, kwestia dopuszczenia do Eucharystii osób rozwiedzionych żyjących w ponownych związkach, dyskusja nad celibatem jako warunkiem pełnienia posługi kapłańskiej. Niektórzy badacze upatrują $\mathrm{w}$ wymogu wewnątrzkościelnego posłuszeństwa, trudnym

9 F.-X. Kaufmann, Kirche in der ambivalenten Moderne, Freiburg im Breisgau 2012, s. 260. 
do pogodzenia z zasadami funkcjonowania człowieka w dzisiejszym świecie, ważnej przyczyny obecnego kryzysu powołań: „Model oparty na wydawaniu rozkazów i posłuszeństwie, odpowiadający logice wczesno-nowożytnej praktyki wojskowej i administracyjnej, sprzeciwia się szczególnie wyraźnie wzrastającej świadomości własnych praw i rozszerzonych możliwości działania ludzi zamieszkujących rozwinięte regiony świata. Na Zachodzie znalazły one wyraz w postulatach Oświecenia - autonomii, równości, partycypacji. Trudno więc się dziwić, że coraz mniej młodych ludzi decyduje się na kapłaństwo; prawdopodobnie ambiwalencje związane $\mathrm{z}$ funkcjonowaniem $\mathrm{w}$ roli podporządkowanego szczególnej dyscyplinie duchownego są dla nich większą przeszkodą niż celibat"10.

Religia zinstytucjonalizowana w formie Kościołów nie wydaje się już współczesnemu człowiekowi czymś oczywistym i przez tę oczywistość zobowiązującym. Przyjmowanie i akceptowanie norm i wartości reprezentowanych przez Kościół nie jest już ułatwione przez wsparcie otoczenia społecznego ani narzucone przez różne formy społecznej kontroli. Religia instytucjonalna nie pełni już na ogół roli czynnika symbolicznej integracji całości społecznej, jedynej prawdy, przez pryzmat której można zrozumieć wszystko, co dzieje się na świecie. Globalizacja i towarzysząca jej pluralizacja życia społecznego sprawiają, że do głosu dochodzą rozmaite style życia lub światopoglądy - religijne lub nie. Docierają one za pośrednictwem mediów do wszystkich: i tych, którzy aktywnie ich poszukują, i tych, którzy biernie absorbują zalew informacji docierających do nich za pośrednictwem telewizji, radia oraz Internetu. Wielość opcji wyboru staje się faktem, a instytucja Kościoła musi odnaleźć się w sytuacji konkurencji wartości, w przestrzeni społecznej, w której obowiązują zasady wolnego rynku, również w sferze światopoglądowej, i której uczestnicy postrzegają siebie samych raczej jako konsumentów, którym przysługuje prawo wolnego wyboru, niż wiernych akceptujących bez zastrzeżeń określony system aksjonormatywny. „Przyzwyczajona do demokracji jednostka nie słucha już Kościoła z przyzwyczajenia czy posłuszeństwa, lecz dlatego, że ma wobec niego sytuacyjne oczekiwania: pragnie pomocy, inspiracji, spokoju i czegoś budującego. Kościół to wprawdzie nie demokracja, ale ma on ciągle do czynienia z demokratycznie usposobionym suwerenem. Przemawia do krytycznie nastawionego religijnego konsumenta, który oczekuje od niego określonych «usług»" ".

Spadek pozycji wartości religijnych w ogólnospołecznej hierarchii wartości pokazują wyniki badań empirycznych prowadzonych nie tylko na Zachodzie, ale również w Polsce. Janusz Mariański prezentuje wyniki badań struktury wartości przeprowadzonych w 2016 r. wśród młodzieży maturalnej. Wśród

10 F.-X. Kaufmann, Kirchenkrise. Wie überlebt das Christentum?, Freiburg im Breisgau 2011, s. 169.

${ }_{11}$ Ch. Florin, Die Herrschaft des Kein - wie die katholische Kirche spricht, w: P. Becker, U. Diewald, Die Zukunft von Religion und Kirche in Deutschland, Freiburg im Breisgau 2014, s. 161. 
wartości sensotwórczych, a więc określających najważniejsze cele, do których respondenci dążą w swoim życiu, naczelne miejsce zajmowała miłość oraz wielkie uczucie (78,7\% odpowiedzi), następnie szczęście rodzinne $(75,5 \%)$, zdobycie ludzkiego zaufania i przyjaciół (58,7\%), wykonywanie pracy, którą się lubi $(51,4 \%)$, znalezienie własnego miejsca w społeczeństwie i poczucie, że jest się w nim przydatnym $(36,4 \%)$, wykształcenie $(34,3 \%)$, dążenie do wybranego celu $(35,7 \%)$. Wśród 14 proponowanych możliwości wyboru wartości religijne znalazły się na niskim, bo dopiero dziewiątym miejscu $\left(25,5 \%\right.$ odpowiedzi) ${ }^{12}$.

Niska pozycja wartości religijnych może być interpretowana jako przejaw spadku społecznego znaczenia religii, jednak możliwa jest tu również inna interpretacja. Można założyć, że spora część respondentów pod pojęciem „wartości religijne" rozumieć mogła nie tyle normy i wartości stanowiące kwintesencję chrześcijaństwa, co raczej te, do których przestrzegania są lub byliby zobowiązani w specyficznej roli członków Kościoła. Takie założenie wiąże się z drugą prawdopodobną przyczyną obecnej sytuacji: tym, że wartości pierwotnie religijne zostają włączone do kultury świeckiej i stają się jej tak oczywistym składnikiem, że mało kto zdaje sobie sprawę z ich religijnej/chrześcijańskiej proweniencji.

\section{Transfer wartości i jego skutki dla instytucji Kościoła}

Jedną z możliwych przyczyn współczesnej sytuacji Kościoła jest rozdzielenie się instytucjonalnie wyspecjalizowanej religii oraz kultury świeckiej ukształtowanej w dużej mierze pod wpływem wartości chrześcijańskich. Najważniejsze składniki chrześcijaństwa - to, co w nim najbardziej istotne i najbardziej fascynujące - stały się składnikiem świeckiego etosu współczesnego społeczeństwa. Natomiast Kościołom, które przyjęły formę organizacji religijnych, pozostało zajmowanie się pozostałymi, partykularnymi elementami chrześcijańskiej tradycji, które nie mają już takiej siły przyciągania i dlatego są przez wielu traktowane jako coś, z czego bez problemu można zrezygnować' ${ }^{13}$.

Wartości wywodzące się z religii przeniknęły do świeckiego życia społecznego w formie zasad regulujących życie społeczne, określanych jako „humanistyczne” lub „demokratyczne”. W ten sposób główne idee chrześcijańskie wpływają na formy ustrojowe i rozwiązania prawne. Wiele $\mathrm{z}$ tego, co uważane jest za osiągnięcie nowoczesności, stanowi formy realizacji najważniejszych postulatów chrześcijaństwa i innych religii światowych. Idee chrześcijańskie wywierają znaczący wpływ na sposoby myślenia i działania człowieka współczesnego,

12 J. Mariański, Maturzyści puławscy w latach 1994-2016. Szkic do portretu młodych Polaków (w druku).

13 F.-X. Kaufmann, Kirchenkrise..., s. 92. 
niekoniecznie kojarząc się przy tym explicite z chrześcijaństwem. Na przykład Carl Schmitt pokazuje, w jaki sposób nowożytna myśl państwowa nawiązuje do dawnych modeli teologicznych. Jego zdaniem „wszystkie najbardziej znaczące pojęcia nowoczesnej nauki o państwie to zsekularyzowane pojęcia teologiczne"14. Zdaniem Karla Löwitha charakterystyczna dla nowoczesnego społeczeństwa wiara w postęp to swoista wersja zsekularyzowanej eschatologii ${ }^{15}$.

W szczególny sposób wpływ idei chrześcijańskich na kształtowanie się nowoczesnej kultury widoczny jest w doktrynie praw człowieka, która ma swoje źródło w chrześcijańskim rozumieniu osoby. Idea godności osoby ludzkiej oraz zasada pomocy słabszym i wykluczonym kształtują przekonania większości współczesnych i znajdują swoje odzwierciedlenie w funkcjonowaniu współczesnych instytucji. Etos miłości chrześcijańskiej i solidarności jest wciąż wysoko ceniony w społeczeństwie, choć niekoniecznie ma przełożenie na konkretne działania. Religijne źródła mają również inicjatywy na rzecz pokoju, likwidacji przemocy w relacjach międzyludzkich, równouprawnienia i tolerancji, przeciwdziałania uprzedzeniom i stereotypom, pomocy socjalnej, szeroko rozumianej sprawiedliwości społecznej i pomocy humanitarnej.

Artysta Josef Beuys określił niegdyś wpływy kultury chrześcijańskiej widoczne w zasadach konstytuujących nowoczesny porządek społeczny mianem ,impulsu Chrystusowego"; jest on pielęgnowany i przekazywany kolejnym pokoleniom $\mathrm{w}$ dużej mierze przez wiernych świeckich, którzy stosują zasady wiary w praktyce życiowej, w rozwiązywaniu dylematów natury moralnej, i wcielają je w życie w konkretnych działaniach na rzecz tych wszystkich, którzy potrzebują pomocy ${ }^{16}$.

Taka sytuacja jest korzystna z punktu widzenia chrześcijaństwa, jednocześnie jednak stanowi pewien problem dla Kościoła. Jej pozytywną stroną jest to, że cała kultura staje się niejako „bardziej religijna”, ponieważ najważniejsze postulaty chrześcijaństwa są realizowane nie tylko ze stricte religijnych pobudek. Podstawowe elementy nauki moralnej chrześcijaństwa przenikają do powszechnej świadomości i stają się składnikiem ogólnie uznawanej elementarnej moralności ${ }^{18}$. Jednocześnie jednak w świadomości społecznej zawęża się wyobrażenie na temat tego, co właściwie jest religią i Kościołem. Szczególnie Kościół coraz bardziej kojarzony jest z wymiarem instytucjonalnym, często dość luźno powiązanym z tym, co stanowi istotę chrześcijaństwa.

14 C. Schmitt, Politische Theologie. Vier Kapitel zur Lehre von der Souveränität, Berlin 1934, s. 49.

15 K. Löwith, Weltgeschichte und Heilsgeschehen. Die theologischen Voraussetzungen der Geschichtsphilosophie, Berlin 2004, s. 69-70.

16 F.-X. Kaufmann, Kirche in der ambivalenten Moderne, Freiburg im Breisgau 2012, s. 313.

17 H. Knoblauch, Ekstatische Kultur. Zur Kulturbedeutung der unsichtbaren Religion, w: Moderne Zeiten. Reflexionen zur Multioptionsgesellschaft, red. A. Brosziewski, T.S. Eberle, Ch. Maeder, Kon$\operatorname{stanz} 2001$, s. 154.

18 F.-X. Kaufmann, Kirchenkrise..., s. 179. 


\section{Ukościelnienie, czyli co deformuje obraz Kościoła}

Już w latach 70. minionego wieku Franz-Xaver Kaufmann diagnozował, że rozwój instytucjonalnego chrześcijaństwa pod wpływem przemian zachodzących w społeczeństwie nowoczesnym zmierza do jego instytucjonalnej specjalizacji, którą określił mianem „ukościelnienia”. „Oznacza to, że chrześcijaństwo nie tworzy już obejmującego wszystkie aspekty życia systemu wartości, lecz znajduje swoje wyłączne miejsce w Kościołach, przybierających w coraz większym stopniu formę organizacji klerykalnych, w których teologowie i księża lub zakonnicy, jako «specjaliści do spraw religii», roszczą sobie wyłączne prawo do sprawowania funkcji duchowych przewodników wobec tzw. laikatu"19.

Taka specjalizacja Kościołów z organizacyjnego punktu widzenia jest korzystna, ułatwia bowiem adaptację do zmieniających się struktur społecznych i pozwala na sprawne funkcjonowanie w nowoczesnym „społeczeństwie organizacji”. Jednocześnie jednak stanowi przeszkodę w identyfikowaniu się wiernych z Kościołem. W coraz powszechniejszym społecznym rozumieniu Kościół utożsamiany jest $z$ instytucją i jej strukturami administracyjnymi; to nie tyle wspólnota wierzących, lecz organizacja hierarchiczna i jej przedstawiciele. Koncentracja religii w sferze związanej z Kościołami i stopniowe wycofywanie się z pozostałych sfer życia sprawia, że religia oddziela się stopniowo od świata codziennych doświadczeń i centralnej dla współczesnego człowieka problematyki poszukiwania własnej tożsamości oraz sensu egzystencji.

Termin „ukościelnienie” nie jest zbyt często używany we współczesnym dyskursie o Kościele, jednak wydaje się, że w podobnym znaczeniu papież Franciszek używa pojęcia „klerykalizm”, wskazując na to, że kojarzenie Kościoła głównie z organizacją prowadzi do umniejszania jego znaczenia poprzez niedocenianie potencjału świeckich wierzących, a także tworzenie niepotrzebnych podziałów między wspólnotą wiernych a "religijnymi specjalistami”: „Nie sposób wyobrazić sobie nawrócenia działania kościelnego bez aktywnego udziału wszystkich członków ludu Bożego. Ponadto, za każdym razem, gdy staraliśmy się zastępować, wyciszyć, pomijać, ograniczać lud Boży do małych elit, tworzyliśmy wspólnoty, plany, akcenty teologiczne, duchowości i struktury bez korzeni, bez pamięci, bez twarzy, bez ciała, w ostatecznym rachunku - bez życia. Ukazuje się to wyraźnie w niewłaściwym sposobie rozumienia władzy w Kościele [...] jakim jest klerykalizm, ta postawa, która «nie tylko anuluje osobowość chrześcijańską, ale także dąży do pomniejszania i niedoceniania łaski chrzcielnej, jaką Duch Święty zaszczepił w sercach naszych ludzi» ${ }^{20}$.

19 Tamże, s. 89.

20 Por. Carta del santo Padre Francisco al Pueblo de Dios que peregrina en Chile, 31 de mayo de 2018. 
Klerykalizm, któremu sprzyjają zarówno sami kapłani, jak i świeccy, tworzy rozłam w ciele eklezjalnym" ${ }^{\prime 21}$.

W przekazie medialnym, który wywiera rosnący wpływ na kształtowanie świadomości współczesnego człowieka i jego przekonań, Kościół funkcjonuje niemal wyłącznie jako instytucja. Mówi się więc o relacjach prawnych i politycznych między państwem i Kościołem, relacjonuje publiczne uroczystości z udziałem dostojników kościelnych, częstym tematem dyskusji są lekcje religii w szkołach, w ciągu ostatnich lat dużym zainteresowaniem cieszą się doniesienia o skandalach obyczajowych oraz związanych z gospodarowaniem funduszami pozostającymi w dyspozycji Kościoła. Natomiast sprawy dotyczące bezpośrednio chrześcijańskiego przekazu wiary rzadko stają się tematem relacji medialnych. Jedynie wąski krąg odbiorców śledzi nauczanie papieży czy współczesne dyskusje teologiczne. To, co odnosi się do sensu istnienia Kościoła (przekaz Dobrej Nowiny), pozostaje w mediach niemal całkowicie niezauważone. Kościół zaczyna więc kojarzyć się nie z tym, co stanowi jego istotę i sedno, lecz ze sprawami mało istotnymi dla przeciętnego współczesnego człowieka, nawet wówczas, gdy jest on osobą wierzącą. W takiej sytuacji słabości funkcjonowania instytucjonalnych struktur Kościoła rzutują na cały jego obraz w oczach opinii publicznej.

\section{Współczesne zadania Kościoła w sferze wartości}

Zdaniem Michaela N. Ebertza, w obecnej sytuacji definiowanej jako kryzys Kościół ma możliwość zareagowania przynajmniej na pięć różnych sposobów. Pierwsza możliwa reakcja to instytucjonalna stabilizacja. Miałaby ona polegać na utrzymaniu dotychczasowych struktur organizacyjnych oraz tradycyjnych zasad regulujących działania duchownych i laikatu, z nadzieją, że skoro okazywały się one skuteczne na przestrzeni wieków, to dziś również zagwarantują skuteczność działań Kościoła i jego wpływ na wiernych. Druga możliwa opcja to fundamentalizm. Na pierwszy rzut oka może ona niewiele różnić się od poprzedniej, jednak charakterystyczne dla niej jest silniejsze podkreślanie różnic między Kościołem a „światem”, różnic pomiędzy religiami oraz między poszczególnymi wyznaniami chrześcijańskimi, a także - w szczególnych przypadkach - również kwestionowanie prawdziwości i prawomocności innych tradycji religijnych. Trzecia możliwa reakcja to pragmatyczna samoregulacja. Jest to postawa daleko idącej otwartości na wszelkie zmiany dokonujące się w otoczeniu społecznym Kościołów, połączona jednak z tendencją do swoistego „lawirowania” wśród różnych tendencji kulturowych w oparciu o założenie, że w Kościele każdy

${ }^{21}$ List do Ludu Bożego 20 sierpnia 2018, http://www.katolsk.no/nyheter/2018/08/201eklerykalizm-tworzy-rozlam-w-kosciele-eklezjalnym201d-list-papieza-1 [dostęp: 27.11.2019]. 
powinien znaleźć coś dla siebie. Nietrudno zauważyć, że taka opcja budzi duże wątpliwości natury teologicznej: istnieje tu niebezpieczeństwo rozmywania się tożsamości Kościoła i utraty spójności jego nauczania na skutek zbyt daleko idącej tendencji do adaptacji do nowoczesnych trendów kulturowych. Kolejna możliwość to koncepcja Kościoła jako elitarnej mniejszości. W tej opcji Kościół, świadom tego, że nie może już wywierać wpływu na całość życia społecznego, niejako wycofuje się z niego, uzasadniając to biblijnym cytatem o Królestwie Bożym, które „nie jest z tego świata”. Ostatnia możliwość to opcja uczenia się: zakłada się tu nieuchronność zmian kulturowych i wynikające z niej zmiany form, w jakich ludzie w świecie współczesnym poszukują Transcendencji. Zamiast jednak okopywać się na swoich pozycjach, odrzucać inaczej myślących i ubolewać nad sekularyzacyjnymi tendencjami w kulturze współczesnej, Kościół decyduje się na służbę człowiekowi w każdych warunkach: wierzącemu i niewierzącemu, stosującemu się do wymogów instytucjonalnych lub kontestującemu je. Wymaga to oczywiście nie tylko zmian w mentalności jego przedstawicieli, ale niejednokrotnie również zmian strukturalnych: rozwijającego się Kościoła w rozwijającym się społeczeństwie ${ }^{22}$.

W obecnej sytuacji zażegnanie kryzysu społecznej pozycji Kościoła będzie możliwe, gdy podejmie on trud ułożenia na nowo swoich relacji ze społeczeństwem. Zależy to w dużym stopniu od tego, na ile będzie w stanie jako instytucja odbudować swój autorytet i społeczne uznanie w nowych warunkach. Nie może już bazować na „charyzmacie urzędu”, lecz na konkretnych działaniach - bardziej instytucjonalnych niż jednostkowych - pokazujących, że przestrzegane w nim są najwyższe standardy, również w dziedzinie moralności. Badania pokazują bowiem, że zarówno w krajach zachodnich, jak i w Polsce wierni na ogół dobrze oceniają duchownych, których znają osobiście. Częściej szwankuje natomiast oficjalno-urzędowa komunikacja między przedstawicielami Kościoła - instytucji i świeckimi wiernymi oraz szerzej pojętą opinią publiczną ${ }^{23}$.

Jedną z możliwości zaradzenia kryzysowi Kościoła jest włączenie w jego instytucjonalne gremia w większym niż dotychczas stopniu wiernych świeckich, co z jednej strony umożliwiłoby powierzenie im części odpowiedzialności za działanie instytucji, z drugiej zaś zapewniłoby większą przejrzystość i kontrolę jej działań. „Przyszłość Kościoła katolickiego w Niemczech będzie czasem laikatu: mężczyzn i kobiet, dla których będzie to podwójne wyzwanie: ponoszenia współodpowiedzialności za Kościół oraz dawania świadectwa w imieniu Kościoła

22 M.N. Ebertz, Päpstlicher Kirchenkurs. Die Option der elitären Minorisierung, w: Entweltlichung der Kirche?, red. J. Erbacher, Freiburg im Breisgau 2012, s. 125-139.

23 M.N. Ebertz, Erosion der (katholischen) Kirche. Altes flicken oder neues wagen?, w: P. Becker, U. Diewald, Die Zukunft von Religion und Kirche in Deutschland, Freiburg im Breisgau 2014, s. 43. 
i głoszonej przezeń prawdy w dzisiejszym i przyszłym świecie. Chrześcijanie stoją rzeczywiście w obliczu zadania nadania nowego kształtu instytucji Kościoła"24.

Niemiecki kardynał Reinhard Marx, przewodniczący Konferencji Episkopatu Niemiec, zwraca uwagę na niezwykle istotną rolę komunikacji w przekazywaniu treści i wartości chrześcijańskich w dzisiejszych czasach: „Chrześcijaństwo jest religią, której centrum stanowi komunikacja: dialog między Bogiem a człowiekiem. [...] Dla Kościoła żyjącego w duchu Ewangelii konieczne jest włączenie się w debatę, która toczy się w otwartym, zróżnicowanym i nawykłym do dyskutowania społeczeństwie, a to $\mathrm{z}$ kolei wymaga intensywnego zaangażowania się w próbę zrozumienia innych punktów widzenia. W warunkach «konkurencji światopoglądowej» Kościół musi zarówno słuchać innych, jak i dołączać swój głos i swoje stanowisko do ogólnej dyskusji"25. Dlatego niezwykle ważne są starania o stworzenie wielu forów, na których można by wymieniać się poglądami na temat kwestii szczególnie istotnych dla współczesnego człowieka.

Przekazywanie treści i wartości chrześcijańskich nie będzie zatem skuteczne, jeżeli będzie się opierać na jednostronnej, odgórnej komunikacji. Ze znacznie lepszym społecznym odbiorem spotka się natomiast każda próba dialogu, porozumienia i otwartej dyskusji o kwestiach spornych. W ten sposób osoby zainteresowane sprawami związanymi z religią i duchowością będą mogły mieć poczucie, że ich problemy i wątpliwości są traktowane poważnie, że Kościół stara się dać odpowiedź - w duchu chrześcijańskim - na pytania egzystencjalnie ważne, a nie tylko głosi etykę przestrzegania nakazów i zakazów, które dla wielu współczesnych są niezrozumiałe. Angażując się w taką dyskusję, trzeba jednak założyć, że nie zawsze będzie ona miała przebieg zgodny z oficjalnym stanowiskiem Kościoła.

W kulturze indywidualizacji Kościół nie może liczyć na pozytywny odbiór społeczny, jeśli będzie starał się występować w roli instytucji nakazująco-pouczającej, niepodważalnego autorytetu i stróża moralności publicznej. W ten sposób sam niejako stawia się ponad społeczeństwem obywatelskim, wpisując się w nieaktualny od czasów Soboru Watykańskiego II schemat podziału na „Kościół nauczający” (hierarchia) i „Kościół słuchający” (wierni). Fakt, że nie wszyscy katolicy akceptują taką formę komunikacji, będzie przez tradycyjnie usposobionych przedstawicieli Kościoła interpretowany jako przejaw sekularyzacji czy wręcz sprzeniewierzenia się wierze lub samemu Bogu. Stąd tylko krok do zamiany Kościoła w enklawę działającą nie wewnątrz społeczeństwa obywatelskiego, lecz na jego obrzeżach, i do mentalności „oblężonej twierdzy”,

24 Tamże, s. 47.

25 R. Marx, Religion und Kirche heute - ist die Zukunft schon vergangen?, w: P. Becker, U. Diewald, Die Zukunft von Religion und Kirche in Deutschland, Freiburg im Breisgau 2014, s. 94. 
ograniczającej oddziaływanie Kościoła do grona wiernych wyznawców zamiast do wszystkich członków społeczeństwa ${ }^{26}$.

Niezwykle istotny dla udanej komunikacji jest język, jakim posługują się partnerzy dialogu. Język może zachęcać lub zniechęcać do dialogu, budować mosty lub stawiać mury, włączać lub wykluczać. Christiane Florin, analizując wypowiedzi wybranych hierarchów na odbywającym się w Rzymie w roku 2012 synodzie biskupów poświęconym nowej ewangelizacji, wskazuje na to, że szczególnie przedstawiciele obozu konserwatywnego mają tendencję do posługiwania się językiem dystynktywnym, wyznaczającym granice między Kościołem a „światem”, który często jest przedstawiany jako zagrażający, a nawet wrogi. Dużo miejsca poświęca się krytyce rozmaitych tendencji rozwoju społecznego, które jawią się jako niekorzystne z punktu widzenia Kościoła. Odbiorcy tego typu komunikatów dowiadują się więc przede wszystkim tego, czym wiara nie jest. Homilie często koncentrują się na ostrzeżeniach przed relatywizmem, synkretyzmem, podążaniem za „duchem czasu”, sprzeciwie wobec reform strukturalnych i wprowadzaniu nowych elementów do liturgii, krytyce współczesnych zmian w strukturze i funkcjach rodziny: „Konserwatysta obawia się ciągle strat i upadku. Wie, czego nie chce. Ten, kto mówi w ten sposób, jest w swoim środowisku zwykle chwalony za swoje «jasne stanowisko». Ale jednocześnie nie wyjaśnia, do czego tak naprawdę zaprasza Kościół"27. Tymczasem język, którym współcześnie można głosić wiarę, to język zrozumiały i niewykluczający, który nie bazuje na utartych sloganach, lecz odnosi się wprost do problemów, z którymi na co dzień zmagają się osoby wierzące. Chodzi o przedstawianie prawd wiary i wywodzących się z nich wartości w taki sposób, żeby można było dostrzec ich nieprzemijającą aktualność.

\section{Uwagi końcowe}

Mimo że sytuacja Kościoła w społeczeństwie zmienia się w zależności od epoki i aktualnych tendencji kulturowych, w rzeczywistości ma on do zrealizowania wciąż te same zadania wynikające $\mathrm{z}$ wartości zawartych w Ewangelii. Kościoły chrześcijańskie nawet w silnie zsekularyzowanych społeczeństwach zachodnich są cenione jako instytucje występujące w obronie takich wartości jak sprawiedliwość społeczna, pokój między narodami i przedstawicielami różnych religii, ochrona przyrody rozumiana jako troska o dzieło stworzenia. Przedstawiciele Kościołów chrześcijańskich angażują się w działania ekume-

26 K. Gabriel, Alte Probleme und neue Herausforderungen, w: P. Becker, U. Diewald, Die Zukunft von Religion und Kirche in Deutschland, Freiburg im Breisgau 2014, s. 25.

27 Ch. Florin, Die Herrschaft des Kein - wie die katholische Kirche spricht, w: P. Becker, U. Diewald, Die Zukunft von Religion und Kirche in Deutschland, Freiburg im Breisgau 2014, s. 163. 
niczne, akcje na rzecz oddłużenia krajów Trzeciego Świata, w pokojowe rozwiązywanie międzynarodowych konfliktów. Niezwykle istotna wydaje się rola Kościołów w stabilizacji porządku społecznego opartego na chrześcijańskich zasadach, nie wszystkie bowiem problemy demokratycznego ustroju państwowego oraz społeczeństwa obywatelskiego dadzą się rozwiązać za pomocą środków administracyjno-prawnych. Wiele wartości promowanych w kulturze nowoczesnej ma charakter stricte materialistyczny; część z nich stoi w jawnej sprzeczności z podstawowymi normami etycznymi, dlatego Kościół może nadal pełnić w społeczeństwie rolę instancji moralnej.

Przed Kościołem współczesnym otwiera się szerokie pole do działania w ramach społeczeństwa obywatelskiego jako instytucji pośredniczącej. Religia, jak wskazuje choćby jej źródłosłów (religare), ma za zadanie łączyć, pośredniczyć, spajać na nowo w całość to, co uległo rozszczepieniu. Taka spajająca rola Kościoła w różnych aspektach życia społecznego i religijnego może ujawniać się na różne sposoby. Kościół może, poprzez dialog z różnymi wizjami społecznego życia, przedstawiać bogactwo swojej aksjologii, włączać ją do społecznego dyskursu, optując za solidarnością, ochroną najsłabszych i wykluczonych, uświadamiając społeczeństwu, że dobro wspólne nie jest tylko sumą osobistych interesów i preferencji jednostek. Może pobudzać do refleksji nad normatywnymi podstawami życia społecznego, wspierać kulturę polityczną, zachęcając do dialogu i sprzeciwiając się wszelkim formom wrogości i wykluczania w sferze publicznej. Może pośredniczyć między formami indywidualnej duchowości a sferą społeczną, włączając wiernych w różne formy uwspólnotowienia działające wraz z innymi - niekoniecznie o tych samych poglądach - na rzecz dobra ogółu. Sytuacja Kościoła nawet w zsekularyzowanych i wielokulturowych społeczeństwach zachodnich nie jest tak zła, jak można by wnioskować z niektórych prognoz. Badania pokazują, że większość członków społeczeństwa - zarówno wierzących, jak i niewierzących - uważa, że Kościół jest w społeczeństwie potrzebny, choć respondenci niekoniecznie mają tu na myśli funkcje religijno-duchowe ${ }^{28}$.

Przekazywanie treści kluczowych dla życia jednostki, takich jak wartości i przekonania (również - a może szczególnie - religijne), jeśli ma być skuteczne, musi odbywać się w bezpośrednich relacjach interpersonalnych. Isolde Karle podkreśla, że szczególną siłą Kościoła była zawsze obecność jego przedstawicieli „na miejscu”, w środowisku lokalnym, w bieżącym życiu społeczności. Struktury instytucjonalne nie są w stanie przekazać przekonań religijnych; nie wystarczy do tego organizowanie nabożeństw czy lekcji religii. Wiara może rozwijać się we wspólnocie, w bezpośrednim kontakcie $\mathrm{z}$ drugim człowiekiem ${ }^{29}$.

28 M.N. Ebertz, Erosion der (katholischen) Kirche, s. 43.

29 I. Karle, Sinn für unlösbare Fragen, w: P. Becker, U. Diewald, Die Zukunft von Religion und Kirche in Deutschland, Freiburg im Breisgau 2014, s. 116. 
We współczesnym zracjonalizowanym społeczeństwie Kościół ma do zrealizowania niezwykle trudne zadanie. To, co głosi, przekracza możliwości ludzkiego poznania, nie jest możliwe do empirycznego sprawdzenia, a często wydaje się sprzeczne z ludzkim sposobem myślenia i wartościowania. Tym, co może umożliwić przyjęcie takiego przekazu, jest zaufanie. Aby je zbudować i podtrzymywać, konieczne jest podjęcie wysiłku ukierunkowanego na przejrzystość działań, szczególnie w przypadkach trudnych; brak transparentności w takich sytuacjach może budzić nieufność nie tylko tych, którzy działaniom Kościoła przyglądają się z zewnątrz, lecz także jego członków, którzy się z nim identyfikują. Autorytet instytucji Kościoła we współczesnym społeczeństwie jest wciąż potrzebny; dotyczy to w równej mierze krajów zachodnich, jak i wciąż jeszcze tradycyjnie katolickiej Polski. Aby jednak w obliczu współczesnych przemian hierarchii wartości okazał się trwały, powinien być budowany na nowych podstawach: już nie jako „autorytet urzędu”, lecz „autorytet zaufania”.

\section{Bibliografia}

Carta del santo Padre Francisco al Pueblo de Dios que peregrina en Chile, 31 de mayo de 2018. Ebertz M.N., Erosion der (katholischen) Kirche. Altes flicken oder neues wagen?, w: P. Becker, U. Diewald, Die Zukunft von Religion und Kirche in Deutschland, Freiburg im Breisgau 2014, s. $29-47$.

Ebertz M.N., Päpstlicher Kirchenkurs. Die Option der elitären Minorisierung, w: Entweltlichung der Kirche?, red. J. Erbacher, Freiburg im Breisgau 2012, s. 125-139.

Florin Ch., Die Herrschaft des Kein - wie die katholische Kirche spricht, w: P. Becker, U. Diewald, Die Zukunft von Religion und Kirche in Deutschland, Freiburg im Breisgau 2014, s. 157-168.

Gabriel K., Alte Probleme und neue Herausforderungen, w: P. Becker, U. Diewald, Die Zukunft von Religion und Kirche in Deutschland, Freiburg im Breisgau 2014, s. 13-28.

Inglehart R., The silent Revolution, Princeton 1977.

Karle I., Sinn für unlösbare Fragen, w: P. Becker, U. Diewald, Die Zukunft von Religion und Kirche in Deutschland, Freiburg im Breisgau 2014, s. 111-119.

Kaufmann F.-X., Kirche begreifen. Analysen und Thesen zur gesellschaftlichen Verfassung des Christentums, Freiburg 1979.

Kaufmann F.-X., Kirche in der ambivalenten Moderne, Freiburg im Breisgau 2012.

Kaufmann F.-X., Kirchenkrise. Wie überlebt das Christentum?, Freiburg im Breisgau 2011.

Kaufmann F.-X., Wie überlebt das Christentum?, Freiburg 2000.

Knoblauch H., Ekstatische Kultur. Zur Kulturbedeutung der unsichtbaren Religion, w: Moderne Zeiten. Reflexionen zur Multioptionsgesellschaft, red. A. Brosziewski, T.S. Eberle, Ch. Maeder, Konstanz 2001, s. 153-168.

List do Ludu Bożego 20 sierpnia 2018, http://www.katolsk.no/nyheter/2018/08/201eklerykalizm-tworzy-rozlam-w-kosciele-eklezjalnym201d-list-papieza-1 [dostęp: 27.11.2019].

Löwith K., Weltgeschichte und Heilsgeschehen. Die theologischen Voraussetzungen der Geschichtsphilosophie, Stuttgart 1957.

Łodzińska J., Zjawisko wypalenia zawodowego jako efekt zmian cywilizacyjnych. Studium socjologiczne na przykładzie pielęgniarek podlaskich, Warszawa 2018.

Mariański J., Maturzyści puławscy w latach 1994-2016. Szkic do portretu młodych Polaków, Lublin 2019. 
Marx R., Religion und Kirche heute - ist die Zukunft schon vergangen?, w: P. Becker, U. Diewald, Die Zukunft von Religion und Kirche in Deutschland, Freiburg im Breisgau 2014, s. 89-100. Schmitt C., Politische Theologie. Vier Kapitel zur Lehre von der Souveränität, Berlin 1934. Schulze G., Krisen, Zürich 2010. Słownik Języka Polskiego, https://sjp.pwn.pl/sjp/kryzys;2565070.html [dostęp: 27.11.2019]. Wielecki K., Kryzys i socjologia, Warszawa 2012.

\author{
Kryzys Kościoła jako kryzys wartości \\ w niemieckim dyskursie teologiczno-socjologicznym
}

\title{
Streszczenie
}

Artykuł poświęcony jest przemianom następującym w sferze aksjonormatywnej, których skutkiem jest zmiana miejsca i roli Kościoła we współczesnym społeczeństwie, często określana mianem kryzysu. Autorka przedstawia najważniejsze wątki toczącej się od kilku dziesięcioleci w środowisku teologów i socjologów niemieckich dyskusji na temat możliwych przyczyn osłabienia społecznej pozycji instytucji Kościoła oraz sposobów radzenia sobie z tą sytuacją. Problemy Kościoła katolickiego w Niemczech są nieco inne niż w Polsce, jednak zbliżone kierunki przemian społeczno-kulturowych, w tym również tych zachodzących w sferze wartości, sprawiają, że Kościół w Polsce w przyszłości prawdopodobnie będzie musiał stawić czoła podobnym problemom. Potrzebne mogą okazać się pewne zmiany strukturalne oraz pastoralne, które mogłyby się przyczynić do wzrostu wiarygodności i skuteczności głoszenia Ewangelii współczesnemu człowiekowi.

Słowa kluczowe: wartości chrześcijańskie, kryzys Kościoła, kultura współczesna

\section{Church crisis as a crisis of values in the German theological and sociological discourse}

\begin{abstract}
The article is devoted to changes occurring in the axionormative sphere, which result is a change in the situation of the Church in society. It is often referred to as a crisis. The author presents the most important threads of the discussion, which has been going on for several decades in the environment of German theologians and sociologists. They identify the reasons for the weakening of the role of church institutions and point out the possibilities of remedying these problems. The situation of the Catholic Church in Germany is different than in Poland, but similar trends in social and cultural development, including changes taking place in the sphere of values, might lead to the Church of Poland facing similar issues in the future. Therefore, structural and pastoral changes may also be needed in the Polish Church, to increase the effectiveness of preaching the Gospel to modern man.
\end{abstract}

Key words: Christian values, church crisis, contemporary culture 